\title{
Editorial
}

\section{IMMINENT DISASTER REVISITED, AGAIN: THE CRISIS LITERATURE OF CANADIAN HIGHER EDUCATION}

\section{GLEN A. JONES*}

Once, when I was a young student politician, I had a conversation with a kindly bureaucrat in which I expressed my frustration at the provincial government's failure to respond to the financial problems facing the university that I attended. He explained that there was nothing particularly critical or immediate about the concerns my student organization was presenting. "Universities," he said with a wink, "are the only institutions I know of which are in a constant state of crisis."

With the possible exception of "chronic underfunding", the phrase "crisis of ..." may be the most commonly used expression in descriptions of Canadian higher education. A number of conferences, reports, compendiums, and articles have been titled or sub-titled "The Crisis of Canadian Universities", and while the nature of the perceived crisis has varied, the conclusion remains fundamentally the same: the system is on the brink of imminent disaster.

Given what appears to be a growing tendency to describe the problems of Canadian higher education as crises, it is important to recognize what such an assessment implies; and further, it is important to recognize that contributions to this body of work are often flawed. The purpose of this paper is to define the crisis literature of Canadian higher education and discuss a number of problems associated with these publications.

\section{DEFINING THE LITERATURE}

The crisis literature of Canadian higher education is that group of conference papers, monographs, polemics, articles and compendiums which share a general vision of the state of Canadian higher education, a vision of imminent disaster. The literature suggests that the problems facing higher education are critical, and they threaten the very existence of our universities or threaten the nature of higher education as we have come to know it. Higher education is on the edge of a mountain and it is in danger of falling over the brink.

This literature is obviously based on the notion of crisis, which Webster's Ninth New Collegiate Dictionary defines as a "situation that has reached a critical phase," "an unstable or crucial time or state of affairs in which a decisive change is 
impending," or "the decisive moment." The word obviously has connotations of criticality and imminency, and these two factors are important points in defining the literature. The criticality of crisis suggests that, in abstract terms, there is a point at which change is unavoidable, a decisive moment when one is threatened by impending danger. The imminency of crisis suggests that the decisive moment has arrived. The crisis literature of Canadian higher education is that body of work which has, as a common theme, a belief that universities have reached a critical juncture in their history and that steps must be taken immediately to avoid catastrophe.

The nature of this crisis has varied according to the ideas and objectives of the authors or conference organizers. In 1956, the National Conference of Canadian Universities sponsored a conference entitled "Canada's Crisis in Higher Education," during which, according to Axelrod, "the very survival of the country was pinned to the expansion of educational facilities" (1982, p. 23). Conference participants warned that

the problem of the universities has become an emergency of grave national concern, to the certain disadvantage of our progress and standing as a nation, and can only be solved by the energetic and immediate assistance and cooperation of all governments of Canada, of business and industry, and of private benefactors (Bissell, 1957, p. 244).

More recent contributions to the literature have identified a "moral crisis" (Katz, 1986), a "crisis of confidence" and a "crisis of management" (Paquet, 1987) in higher education. The "funding crisis" has been the subject of a number of articles and reports prepared by groups advocating greater government support of universities. Several polemics have argued, using questionable evidence and arguments, that there is a "crisis of mediocrity" involving the quality of education at Canadian universities (Bercuson, Bothwell, and Granatstein, 1984; Frum, 1988). All of these works share a common belief that higher education is in, or is about to enter, a state of crisis.

\section{THE PROBLEM OF PROOF}

One of the most serious shortcomings of much of the crisis literature is a failure to provide convincing evidence that disaster is imminent. The crisis argument often is built on anecdotal reflections, unexplained causal relationships, or case studies supposedly demonstrating what the author assumes to be a sector-wide problem. While the failure to provide convincing evidence in support of an argument does not necessarily imply that the conclusion is incorrect, it does bring the argument into question.

The financial crisis argument, for example, is usually based on the assertion that universities are underfunded and that continued underfunding can only lead to disaster. Skolnik has identified seven categories of data or analysis which have been or could be used to support an argument for additional government support, 
and he suggests that, of the seven, six are seriously deficient (1986). The seventh, program review or assessment, represents an attempt to measure indicators of quality, an approach which is the subject of a great deal of discussion in the United States where accreditation, program review, and outcome assessment are placing new types of pressure on post-secondary institutions (Lincoln, 1988). Assuming that one can measure the quality of university activities and the relationship between quality and government support, it is still unlikely that one could logically support the criticality and immediacy of crisis, or quantitatively characterize the imminent disaster that such an assertion implies.

This raises one of the central problems common to much of the crisis literature, and that is the difficulty, if not the impossibility, of proving the existence of a crisis. It is not enough simply to identify a problem or demonstrate an element of decline concerning Canadian universities. One must provide evidence that the problem is of such a magnitude that a failure to resolve the problem will lead to a decisive moment in which some characteristic of higher education will be threatened. This problem is further complicated by the lack of a theoretical framework within higher education to support the identification or prediction of crisis, except perhaps in the analysis of historical events or trends. While the decline of a specific indicator often can be conceptualized as a downward movement along a quantifiable or qualifiable continuum, the concept of a "decisive moment" or "crucial time" requires a far more complicated framework. The crisis literature may present the reader with evidence of decline, but it often fails to provide evidence to support the suggestion that Canadian universities are on the brink of disaster.

\section{THE PROBLEM OF CRYING WOLF}

A second problem, stemming perhaps from the first, is that the crisis literature, as a body of work, is not progressive. The lack of supporting evidence and a theoretical framework has meant that contributions to the literature are not built or based on other contributions to the literature, and a lack of follow-up work has meant that there has been very little analysis of the validity of these predictions. These problems might lead the readers of this literature to conclude that higher education has been in a constant state of crisis, or that individual contributions to this literature resemble predictions of imminent disaster revisited. Such conclusions are understandable, especially given the repetitive nature of the arguments put forward to advance the cause of university funding. Taken out of their political contexts, such statements give the impression that the financial crisis is a regular or continuous phenomenon, an illogical assertion given the critical and imminent nature of the concept.

These criticisms do not necessarily mean that higher education has not been going through a crisis; rather, they suggest that the literature has, generally speaking, failed to provide evidence to support such an assertion, and that a lack of follow-up has meant that such conclusions have seldom been critically reviewed. 
These problems, combined with the repetitive nature of some arguments, have led observers to suggest that the universities, and some scholars of higher education, are guilty of 'crying wolf' too often.

\section{CONCLUSIONS}

No discussion of the crisis literature would be complete without acknowledging the role that this body of work has played in acquainting the university community, government, and the general public with some of the serious problems facing Canadian higher education; but the flaws inherent to much of this literature cannot be ignored. Writers who use a crisis argument should be asked to justify their statements. Contributions to the literature should be examined and subjected to a number of basic questions: What is a crisis for Canadian higher education? How do we know when a crisis exists?

If we accept the crisis literature at face value then we are guilty of accepting what are, in some cases, poorly supported arguments in favour of a conclusion which is seldom defined. If we blindly accept this conclusion, how will we know when the 'crisis' is over?

\section{SECOND REGARD SUR NOS DÉSASTRES IMMINENTS : LES ÉCRITS SENSATIONNALISTES SUR L'ÉDUCATION SUPÉRIEURE CANADIENNE}

\section{GLEN A. JONES*}

Un jour, comme je faisais mon apprentissage dans le domaine de la politique, j'eus une conversation avec un fonctionnaire bienveillant auquel j'avais exprimé ma frustration face à l'incapacité du gouvernement de ma province de trouver des solutions aux problèmes financiers de l'université que je fréquentais. Il tâcha de m'expliquer que les inquiétudes de mon association étudiante n'étaient pas fondées à court terme et que leurs causes étaient loin d'être aussi terribles qu'elles le paraissaient. «Les universités, continua-t-il en riant du coin de l'œil, sont les seuls établissements que je connaisse à être constamment en état de crise ".

Le mot «crise» est avec l'expression «manque chronique de financement» le terme le plus souvent employé pour décrire l'état de l'enseignement supérieur canadien. Nombreux sont les rapports, conférences, abrégés, et articles qui ont pour titre ou sous-titre : «La crise des universités canadiennes. » Or, si la façon dont on perçoit la nature de la crise peut varier, la conclusion en est fondamentalement la même : notre système est au bord du précipice et le désastre est imminent. 
Comme les auteurs ont de plus en plus tendance à présenter les problèmes de l'enseignement supérieur canadien comme autant de crises, il nous semble important de mettre en lumière ce qu'une telle présentation implique, et d'élucider la faille que leurs écrits possèdent souvent. Nous nous sommes donc donné pour objet dans cet article de montrer ce dont parlent ces écrits sensationnalistes et d'analyser certains des problèmes qui y sont abordés.

\section{LES ÉCRITS SENSATIONNALISTES}

Il se composent d'actes de conférences, de monographies, d'articles et d'abrégés de pamphlets ayant tous en commun une vision globale de la situation de l'enseignement supérieur, vision fondée sur le risque d'un désastre imminent. Ces écrits laissent entendre que les problèmes qui se posent à l'enseignement supérieur sont si graves qu'ils remettent en question l'existence même de nos universités ou du moins le type d'enseignement supérieur que nous avons connu: l'enseignement supérieur se trouve au bord du précipice, et il risque de disparaître à tout moment.

Ces écrits se fondent évidemment sur la notion de crise, mot qui s'applique, si l'on en croit le dictionnaire, à « une situation parvenue à un stade critique », à «une période d'instabilité ou d'importance cruciale, » ou bien encore à «l'état d'une situation parvenue à une phase grave où un changement décisif doit se produire »; enfin il peut être «ce moment décisif» lui-même. Ce mot s'associe bien sûr dans notre esprit à un sentiment de danger grave et imminent, et l'on retrouve ces deux dernières caractéristiques dans les écrits mentionnés plus haut. Cette notion même de gravité suggère qu'il existe un point de non-retour, point que nous ne saurions franchir sans nous trouver soumis à des changements inévitables, ou moment décisif où nous serions exposés à un danger imminent. Le caractère d'imminence qui s'associe au mot crise sous-tend l'idée que ce moment décisif est arrivé. Nous trouvons donc dans les écrits sensationnalistes sur l'enseignement supérieur canadien une conviction commune, celle que les universités sont parvenues à un moment critique de leur histoire et qu'il faut prendre immédiatement des mesures afin d'endiguer la catastrophe.

La nature de cette crise varie quant à elle en fonction des idées et des objectifs des divers auteurs ou des organisateurs de conférences. En 1956, le colloque national des universités canadiennes a proposé une conférence intitulée « La crise de l'éducation supérieure au Canada », conférence au cours de laquelle on aurait, selon Axelrod, insisté sur le fait que «la survie même de notre pays est étroitement liée à l'agrandissement des universités » (1982, p. 23). Les participants à la conférence nous prévenaient en outre déjà des risques que celle-ci courait :

Le problème des universités est parvenu à un état d'urgence tel qu'il pose un problème grave à la nation puisqu'il risque de réduire notre progression ainsi que notre niveau général ; ce problème ne peut donc se résoudre que par une aide 
énergique et immédiate et par une coopération efficace de tous les paliers de gouvernement du Canada, des milieux industriels et commerciaux et des bienfaiteurs privés. (Bissel, 1957, p. 244).

Plus récemment, nous avons pu lire qu'il existait aussi une «crise morale» (Katz, 1986), une «crise de confiance» et une «crise de gestion » (Paquet, 1987) de l'enseignement supérieur. La « crise du financement » a fait l'objet d'un grand nombre d'articles et de rapports issus de groupes en faveur d'une plus grande aide financière aux universités de la part du gouvernement. Des polémistes ont soutenu, à grand renfort de preuves et de raisonnements douteux, qu'il y avait une «crise due à la médiocrité », leur but étant de mettre en doute la qualité de l'enseignement offert par les universités canadiennes (Bercuson, Bothwell et Granatstein, 1984, Frum, 1988). Tous ces travaux ont en commun la conviction que l'enseignement supérieur se trouve, ou est sur le point de se trouver, dans une situation de crise.

\section{LE PROBLÈME DE LA PREUVE}

L'un des défauts les plus graves de la plupart de ces écrits vient du fait qu'ils se montrent incapables de fournir des preuves convaincantes de l'imminence d'un désastre. La raison qui appuie l'existence d'une crise se fonde souvent sur des remarques anecdotiques, sur quelque rapport de cause mal expliqué ou bien sur des études de cas qui devraient selon les auteurs démontrer que le problème touche l'ensemble de ce secteur. Même si le manque de preuves convaincantes à l'appui d'un raisonnement ne veut pas dire systématiquement que les conclusions sont fausses, il ne fait aucun doute qu'il remet forcément l'ensemble du raisonnement en question.

Ainsi, le raisonnement selon lequel il existe une crise financière se fonde généralement sur l'affirmation que les universités reçoivent trop peu d'argent et que si cette situation persiste, elle mènera au désastre. Skolnik a trouvé sept catégories de données ou d'analyses ayant été utilisées ou pouvant l'être pour convaincre le gouvernement de fournir davantage de financement, et il remarque que, sur les sept, six n'ont pour ainsi dire pas été exploitées (1986). La septième, qui touche à l'évaluation des programmes, est en fait une tentative d'évaluation de la qualité ; or, cette perspective est sujette à de nombreuses discussions notamment aux États-Unis où l'accréditation ainsi que l'évaluation des programmes et de leurs résultats font subir de nouvelles pressions aux établissements postsecondaires (Lincoln, 1988). Même si l'on croit que l'on peut mesurer la qualité des activités universitaires et le rapport qui existe entre cette qualité et le montant d'aide financière accordé par le gouvernement, il reste peu probable que l'on puisse démontrer de façon logique que la crise est parvenue à son point critique et que ses conséquences sont imminentes; comment pourrait-on par ailleurs exprimer quantitativement l'imminence du désastre que cette affirmation annoncerait?

En effet, ceci soulève l'un des problèmes les plus fondamentaux que posent ces écrits sensationnalistes : peut-on vraiment prouver l'existence d'une crise? Il ne 
suffit pas d'identifier un problème ou de remarquer un déclin dans les universités canadiennes, il faut fournir des preuves capables de convaincre que le problème a une telle étendue que toute négligence à le résoudre mènerait forcément à ce moment décisif mentionné plus haut où certains des aspects de l'enseignement supérieur seraient menacés. Ce problème se complique de l'inexistence, au sein de l'enseignement supérieur, de fondements théoriques (sauf peut-être historiques ou chronologiques) susceptibles d'appuyer, par des critères précis, l'identification ou la prédiction d'une crise. Alors que l'on peut, à l'aide d'un indice spécifique, représenter un déclin par une courbe quantitative ou qualitative se dirigeant de haut en bas, les concepts de «moment décisif » ou de «période cruciale» requièrent quant à eux un cadre d'analyse beaucoup plus complexe. Les écrits sensationnalistes prouvent peut-être qu'il y a déclin, mais ils ne parviennent pas à prouver que les universités canadiennes sont au bord du désastre.

\section{DEVONS-NOUS HURLER AVEC LES LOUPS ?}

Un second problème, qui est peut-être une conséquence du premier, vient du fait que les écrits sensationnalistes sont en fait, dans l'ensemble fort peu progressifs. Le manque de preuves et de fondements théoriques va de pair avec le fait que ces écrits ne sont pas fondés sur d'autres recherches; il n'y a pas eu non plus de suivi susceptible d'évaluer la validité de ces prédictions. La présentation telle quelle de ces problèmes amène le lecteur à penser que l'enseignement supérieur est dans un état constant de crise et que chaque nouvel écrit ressemble à toutes les prédictions de désastres imminents. Cette interprétation se comprend facilement, d'autant que les arguments avancés se répètent eux aussi, généralement pour obtenir un meilleur financement des universités. Sortis de leur contexte politique, de telles déclarations donnent l'impression que la crise financière est un phénomène normal ou constant, ce qui serait illogique compte tenu des caractères de gravité et d'imminence inhérents à lá notion de crise.

Les critiques que nous présentons ici ne veulent pas dire que l'enseignement supérieur ne connaît pas de crise ; elles veulent dire que les écrits sensationnalistes n'ont pas réussi, d'une façon générale, à prouver ce qu'ils avançaient et que le manque de suivi a engendré un manque de commentaires critiques. Ces problèmes, auxquels s'ajoute la répétition constante de certains arguments, ont mené certains observateurs à penser que les universités, et certains membres de l'enseignement supérieur, se contentaient un peu trop de «hurler avec les loups ».

\section{CONCLUSION}

On ne saurait parler de ces écrits sans reconnaître le rôle qu'ils ont joué pour faire connaître tant aux universitaires et au gouvernement qu'à l'ensemble du public certains des problèmes les plus graves auxquels doit faire face l'enseignement supérieur au Canada. Toutefois les défauts de ces écrits ne doivent pas être passés sous silence. Les auteurs qui parlent de "crise» devraient pouvoir justifier leur 
affirmation. Ces écrits devraient aussi faire l'objet d'un examen au cours duquel on se poserait un certain nombre de questions fondamentales: qu'entend-on vraiment par crise de l'enseignement supérieur? Comment savons-nous s'il y a véritablement une crise?

Si nous acceptons ces écrits tels quels, nous sommes à notre tour coupables d'accepter des raisonnements parfois sans fondements en faveur de conclusions rarement définies. Si nous acceptons aveuglément ces conclusions, saurons-nous jamais quand une crise se termine?

\section{REFERENCES}

Axelrod, P. (1982). Scholars and Dollars: Politics, Economics, and the Universities of Ontario 1945-1980. Toronto: University of Toronto Press.

Bercuson, D.J., Bothwell, R., \& Granatstein, J.L. (1984). The Great Brain Robbery: Canada's Universities on the Road to Ruin. Toronto: McClelland and Stewart.

Bissell, C.T. (ed.) (1957). Canada's Crisis in Higher Education. Proceedings of a conference held by the National Conference of Canadian Universities, Ottawa, November 1956. Toronto: University of Toronto Press.

Frum, L. (1988). Reach For the Mediocre. Saturday Night (September), 103 (9), 36-42.

Katz, M.B. (1986). The Moral Crisis of the University, or, the Tension Between Marketplace and Community in Higher Learning. In W.A.W. Neilson \& C. Gaffield (eds.), Universities in Crisis: A Mediaeval Institution in the Twenty-first Century, Montreal: Institute for Research on Public Policy.

Lincoln, Y.S. (1988). Can Somebody Give Me A Hand Here? Program Reivew, Accreditation Processes, and Outcomes Assessment As the Straws That Are Breaking the Camel's Back. Paper presented at the Annual Meeting of the Association for the Study of Higher Education, St. Louis, MO., November 1988.

Paquet, G. (1987). Post-Secondary Education - An Enterprise Less Than Optimally Managed. In Gilles Paquet and Max von Zur-Muehlen (eds.), Education Canada? Higher Education on the Brink, Ottawa: Canadian Higher Education Research Network.

Skolnik, M.L. (1986). If the Cut Is So Deep, Where Is the Blood? Problems in Research on the Effects of Financial Restraint. Review of Higher Education 9(4), 435-455. 